\title{
FEATURES OF THE SETTLEMENT OF THE CARPATHIAN REGION IN THE CONTEXT OF EUROPEAN CULTURAL DEVELOPMENT
}

\section{Chuyko O. D.}

\section{INTRODUCTION}

The oldest monuments of the Stone Age on the European territory are known until the early 1970s from studies in Germany, the Czech Republic, Slovakia, Romania and Hungary. The discovery of Ukrainian archaeologists not only significantly changed the traditional ideas of the settlement of the Danube-Carpathian area, but also pointed to the Ukrainian Carpathians as the place from which the settlement of people on the territory of modern Ukraine began. As scientists traditionally believed, its settlement took place from the south of Central Europe through the Balkans to East Asia. Based on the discovery of new Paleolithic monuments in the north-eastern foothills of the Eastern Carpathians, Oleksandr Chernysh confirmed that settlements in the Acheulean period ( 1 million - 850 thousand years ago) spread not only bypassing the mountain range, but also directly through passes - Uzhok and Verecke ones ${ }^{1}$. Primitive people, having crossed them, moved further east, inhabiting Transnistria and the Northern Black Sea coast ${ }^{2}$.

The reason for hopes of finding traces of a Stone Age person in the heart of the Carpathians was the discovery of O. Chernysh in the adjacent areas of Chernivtsi region, and especially Mykhailo Klapchuk's one in some areas of neighboring Ivano-Frankivsk region ${ }^{3}$. More than 50 archeological monuments of the Stone Age in the 1960-80s were studied in Deliatyn (Nadvirnianshchyna, Prykarpattia) ${ }^{4}$. Traces of life found here are about 40 thousand years old, when the Neanderthals of the European continent created the Mousterian culture. The main tools at that time were flint chisels, scrapers and chips of massive forms.

Traces of early Paleolithic settlements were discovered on the territory of the Drohobych district of Lviv region. Here, in particular, a collection of tools was collected: chippers, choppers, chisels, massive chips of cutting devices, chips and fragments of plates. According to the processing technique and

\footnotetext{
1 До питання про час і шляхи найдавнішого заселення Східних Карпат людиною давнього кам’яного віку. Нові матеріали з археології Прикарпаття і Волині. Львів, 1992. Вип. 2. С. 13.

2 Пелещишин М., Конопля В. Східнокарпатський регіон у первісності (кам'яний вік). Етногенез та етнічна історія населення Українських Карпат. Археологія та антропологія. Львів, 1999. Т. I. C. 31-41.

${ }^{3}$ Клапчук М. Новые данные о палеолите и мезолите Прикарпатья. Советская археология. Москва, 1983. № 4. C. 103-117.

${ }^{4}$ Клапчук М., Клапчук-Делятин В. Історико-етнографічний нарис Делятинщини (від найдавніших часів до 1939 року) : монографія. Делятин, 2000. С. 14.
} 
types of discovered tools, their similarity to the Stone Age finds in Transcarpathia, Slovakia, the Czech Republic, and Germany is determined ${ }^{5}$.

\section{Features of the region settlement and the period of archaeological cultures}

Scholars have no doubt that the first period of settlement of the Ukrainian Carpathians dated back to the Paleolithic era. "Peculiarities of the Hutsul environment were extremely favorable in terms of ethnic formation, because in that part of the Carpathians there was an interaction of different ethnic groups, or, according to M. Kostomarov, "mutual friction of peoples". The Hutsul phenomenon is largely determined by the geographical location on the "border of cultures", as the ethnographer Mariia Lavruk rightly emphasizes ${ }^{6}$.

The Middle Stone Age settlement ("Sheshory-1") was opened in 1994 in Kosiv district. On the north-eastern outskirts of the current Sheshory village, the remains of a classical Mesolithic site of hunters and gatherers, aged 10-8 thousand years, were recorded. Synchronous tools (nucleuses, scrapers, chips, staples, flint knives) were also found at the site "Sheshory-II" and at the settlement "Kosmach-II"?

Establishing an exact chronology of the Ukrainian Carpathians settlement in the Neolithic, the next period would be impossible without the discovery of Ya. Pasternak of two residential buildings, $9.8 \mathrm{~m}$ and $4.0 \mathrm{~m}$ long, in the "Zapust" area near the Kotovania village. The study of materials and analysis of the buildings filling shows that they belonged to the bearers of the culture of linear pottery ceramics, which is considered one of the most mysterious cultures in the ancient history of Europe ${ }^{8}$. It is believed the bearers of such a culture arrived in present-day Ukraine in the second half of the $5^{\text {th }}$ millennium $\mathrm{BC}^{9}$.

Linear and spiral-meandering compositions of ceramic products are one of the oldest manifestations of artistic creativity of the Neolithic era's inhabitants. According to Ya. Pasternak, they, as well as a plastic ornament with a motif of a bull's head, as well as schematic images of a frog engraved or carved on clay vessels, could have cult significance. The roots of the animal cult are believed to date back to the Paleo-Mesolithic period, but in the days of the tribes of the Linear Pottery culture, the veneration of domestic animals, including cattle, especially the bull, was due to their role in the economy. Apparently, there was a ritual associated with the cult of this animal.

\footnotetext{
5 Черниш О. До питання про час і шляхи найдавнішого заселення східних Карпат людиною давнього кам'яного віку. Нові матеріали з археології Прикарпаття і Волині. Львів, 1992. Вип. 2. C. $12-13$.

6 Лаврук М. Гуцули Українських Карпат : етнографічне дослідження. Львів, 2005. С. 64.

7 Мацкевой Л. До питання про найдавніше минуле Косівщини. Старожитності Косівщини. Історичні нариси. Івано-Франківськ : «Лілея-НВ», 1997. С. 49-52.

8 Пастернак Я. До проблеми поширення і хронології лінійно-стрічкової кераміки в Європі. Авгсбург, 1948. 3б. 2. С. 4-5.

${ }^{9}$ Винокур І., Телегін Д. Археологія України. Тернопіль : Навчальна книга - Богдан, 2005. С. 4-5. 
The pottery of early farmers is a carrier of much information about the life of the ancient population, its work, beliefs, worldview, historical destiny, migration processes and ethnocultural interactions between different communities. The most characteristic elements of the steppe pottery ornament are considered to be mortise horizontal, vertical, oblique, arched lines, as well as small pits. In archeological science, this version of the ceramics' decoration was called "musical ornament" 10 .

Among the ornamental motifs of kitchen pottery found in the settlement in the Kotovania village, Olena Lenartovych singled out three simple elements: 1) finger indentations; 2) nail recesses; 3) plastic adhesives. Often the relief ornamentation, as the scientist noticed, was combined with the deepened one, forming a kind of combined décor ${ }^{11}$.

The remains of adobe buildings, household pits, and numerous fragments of pottery and clay anthropomorphic statuettes were discovered by Larysa Krushelnytska during archeological excavations at the settlement in the Spas village of Kolomyia district of Ivano-Frankivsk region. The connection of Trypillian plastics with the cult of productivity and fertility is indicated by the presence of impurities in cereal grains or coarsely ground flour, in the clay from which the found monuments were made. Such statuettes had a sacred meaning, because in their images Trypillian potters embodied the cult of the Mother-Grandmother as it is now believed. It was a universal image of the Great Mother, because each figure also had a separate sacred purpose (a homemaker, the symbol of the sun, water, earth, grain, the image of the guardian or the tree of life $)^{12}$.

The Carpathian region, as Ukrainian researchers conclude on the basis of archaeological discoveries, was in the zone of influence of Trypillian culture. "Trypillia in the context of the world civilization process can be defined as a farming civilization (protocivilization)," as the archaeologist Mykhailo Videiko emphasizes, "the creators of which laid the foundations of civilized life in the Carpathian-Transnistrian region" ${ }^{\text {"13 }}$.

The main activity of the people of Trypillia, according to scientists, was agriculture, because they grew three varieties of wheat (single-grain, twograin, spelled), barley, millet, and legumes. They harvested with the help of horn wooden sickles with flint inserts. Certainly, such tools were even more efficient than iron sickles. In addition, the population bred animals, mostly cattle, which were also used as a traction force. This is confirmed by drawings on utensils and findings of clay models of sledges drawn by oxen.

\footnotetext{
10 Ленартович О. Елементи орнаменту посуду культури лінійно-стрічкової кераміки 3 поселення Тадані. Наукові студї. Історико-краєзнавчий музей. м. Винники. Львів : «Растр-7», 2012. Вип. 5. С. 4.

11 Ленартович О. Керамічний комплекс поселення культури лінійно-стрічкової кераміки Котоване І. Археологічні дослідження Львівського університету. Львів, 2010. Вип. 13. С. 71-91.

12 Крушельницька Л. Найдавніше населення Карпатського регіону. Українські Карпати. Київ, 1989. С. 20-21.

${ }^{13}$ Відейко М. Трипільська цивілізація. Київ : Наш час, 2008. С. 7.
} 
In their farms, the "first Ukrainian farmers", as Mykhailo Hrushevsky called the people of Trypillia, used tools made mainly of different types of stone, horn bones and wood. Flint was used to make knives, scrapers, sickles, various drills, punctures, and adzes-axes, and other types of stone were used to make grain graters, grinders, hoes, and hammer axes. Punctures, adzes, hoes, plowshares, daggers, battle hammers, fishing hooks were made of bone and horn ${ }^{14}$.

Copper, imported from the Balkans and the Lower Danube, has always been valued in every society. In ancient times, its products were prestigious things, a means of exchange, an object of worship and sometimes served as a measure of value. This metal was used mainly to make jewelry and individual tools. A wedge-shaped copper ax $14.5 \mathrm{~cm}$ long with a through hole near the butt was found in 1910 on the outskirts of the Pistyn village of Kosiv district. M. Bandrivskyi connects this monument with the bearers of the group of Trypillian tribes that left the settlement in the village of Spas of Kolomyia district and the saltworks complex in the village of Loieva of Nadvirna district. According to scientists, in a culture dating back to the beginning of the 4th millennium BC, foundry was not used yet, but only blacksmith's tools: cold and hot forging, turning, highlighting, and polishing ${ }^{15}$.

High artistic quality, perfect shapes and ornaments characterize the ceramics found in the foothills of the Carpathians. Obviously, the masters were well aware of the properties of clay and mastered the technological techniques, which ensured the strength of the products with too thin walls. The dishes were decorated with recessed, ribbed grooves and hand-drawn ornaments painted with red, black, brown and white mineral paints. The image was mainly in the form of a spiral and its elements in combination with various signs, including images of the sun, moon, animals and plants ${ }^{16}$.

One of the reliable sources on the origin and development of art of agricultural tribes that lived in modern Western Ukraine during the Neolithic Revolution, are pysanky (Easter eggs), especially Boiko ones. They have a rich solar ornamentation. Here we see the image of the sun in the form of a radiant circle with lines or dots, and various solar signs: oblique crosses, tetraskeles, "mills" and "windmills". Ethnographer Vadym Shcherbakivskyi (1876-1957) was inclined to think that the ornament of Ukrainian pysanky has a dominant element that reflects the cult of the sun ${ }^{17}$.

Art analysis of more than 600 specimens of Boiko pysanky allowed Mykhailo Skoryk to notice numerous varieties of swastika or triquetra ${ }^{18}$, in

\footnotetext{
${ }^{14}$ Грушевський М. Історія України-Руси : в 11 т. 12 кн. Київ : Наук. думка, 1994. Т. 1.

15 Бандрівський М. Археологія Косівщини і суміжного з нею краю. Старожитності Косівщини. Івано-Франківськ : Лілея-НВ, 1997. С. 65.

${ }^{16}$ Ткачук Я. Мистецтво Покуття. Історико-етнографічне та мистецьке життя Покуття: минуле $i$ сьогодення : матеріали науково-теоретичної конференції 3 питань дослідження історикоетнографічного регіону Покуття (м. Коломия, 9 жовтня 2011 року). Коломия : Вік, 2013. С. 56-69.

17 Щербаківський В. Основні елементи орнаментації українських писанок та їх походження. Праці відділу українознавства. Київ; Оттава, 1990. Т. 7. С. 3-29.

${ }_{18}$ Скорик М. Бойківські писанки. Літопис Бойківщчини. 1934. Ч. 4. Табл. 3, с. 16-19.
} 
particular with rounded horns, processes ${ }^{19}$. According to the scientist, such an artistic element of pysanky of Boikivshchyna as the "Greek cross" from the swastika when connecting the ends of the hooks with the center. Among the decor of Boiko pysanky there are double and single swastikas, varieties of single and double triquetras, rosettes with eight or six petals. In addition to conventional symbols on such works of folk culture, the real images of the sun and stars can be seen.

The spiral motif is also common on Boiko pysanky. In some compositions it is shown independently, and in others - as part of more complex artistic solutions. According to V. Darkevich, the motif of paired spirals is explained by their symbolic meaning of the dichotomy of all nature. The right scroll expresses development, growth, morning, spring, development, while the left one - fading, autumn, evening, end ${ }^{21}$.

It is believed that the spiral motif originated in agricultural tribes since the Eneolithic as a symbolic image of the movement of the sun in the sky ${ }^{22}$.

Approximately in the middle of the 4th millennium BC the population of Prykarpattia mastered foundry. One of the proofs of this can be a small treasure of copper things in the Trypillian painted pot, found in 1895 in the village of Horodnytsia (Horodenka district of Ivano-Frankivsk region). The set of monuments consisted of a flat adze-ax, a wedge-shaped ax, a dagger, fragments of a tiara and several dozen beads ${ }^{23}$.

Archaeological excavations in the Carpathian Hills and in the Beskids conducted initially by Polish and in recent years by Slovak expeditions, uncovered many monuments from different times. They indicate favorable conditions for agriculture and animal husbandry in some mountainous areas. Accordingly, the conclusion concerning their settlement by agricultural tribes of the culture of funnel-shaped ware since the 4th millennium BC is reliable ${ }^{24}$.

At the turn of the 3rd-2nd millennium BC, after the cessation of the Eneolithic cultures - Trypillian, funnel-shaped vessels, spherical amphorae in most of Central and Eastern Europe, numerous tribes were formed, which left behind the cultural monuments of corded ware. Four mounds of the Bronze Age near the Kulchytsi village in Sambir region were the object of attention of Ya. Pasternak ${ }^{25}$, later research at the Kulchytskyi Eneolithic Cemetery was continued by Ihor Sveshnikov.

\footnotetext{
${ }^{19}$ Там само, с. $20-27$.

${ }^{20}$ Там само, с. $28-32$.

21 Даркевич В. Топор как символ Перуна в древнерусском язычестве. Советская археология. 1961. № 4. С. 94. C. 33 .

22 Рибаков Б. Макрокосм в микрокосме народного искусства. Декоративное искусство. 1975. № 1.

23 Андрухів I. Давня історія України та рідного краю з найдавніших часів до IX ст. ІваноФранківськ, 1997. С. 62.

24 Махнік Я. Інтердисциплінарні дослідження над найдавнішим заселенням польських і словацьких Карпат. Бойківщина: Історія та сучасність : матеріали Міжнародного істориконародознавчого другого семінару «Населення Бойківщини в контексті загальнокарпатського етнокультурного розвитку». (м. Самбір, 14-16 вересня 1995 р.). Львів; Самбір, 1995. С. 58-59.

25 Пастернак Я. Шнурова могила в Кульчицях. Літопис Бойківщини. Самбір, 1936. Ч. 7. С. 1-3.
} 
As for the spiritual life of the Carpathian communities, according to Mykola Peleshchyshyn and Larysa Krushelnytska, the traditions, customs, religious ideas, artistic preferences inherent in a large array of early IndoEuropean tribes in Europe spread among them. Certainly, the leading role is believed to have been played by beliefs about the existence of the soul, the relationship between life and the afterlife, the cult of ancestors. It was not at that time that burial mounds first appeared in Podkarpackie, the custom of sprinkling the dead with red ocher, which "symbolized blood, life, cremation as purification by fire" 26 .

An important stage in the settlement of the Carpathian region dates back to the Bronze Age (2nd-1st millennium BC). The flourishing of the local bronze foundry is believed to have been triggered by the arrival in the Carpathians of the Noah culture tribes from Priprut Romania. As the researchers conclude, although the residents of Prykarpattia did not have deposits of copper, tin, zinc, but received copper-bronze products or shapeless copper or already bronze scrap by exchange with neighboring tribes, mainly from Transcarpathia. Naturally, this supported the borrowing of other people's artistic achievements and the transfer of their own. This was facilitated by the mountain passes, which since the Stone Age had become economic communications.

Archaeologists found traces of bronze foundry, established in the late 2nd millennium BC in the settlement near the Ostrivets village (Horodenka district of Ivano-Frankivsk region). Remains of four bronze foundry furnaces and the ruins of a building with furnaces for additional processing of bronze products were discovered there. In the complex of monuments there were stone molds for casting the tip of a spear, a chisel, an adze, an awl and a discshaped candle, three unhewn stone tiles from sandstone ${ }^{27}$.

Multi-vector contacts of the ancient population of Prykarpattia with neighbors confirm numerous findings. In particular, the items that were part of the Ostrivets treasure, which dated back to the end of the 2nd millennium $\mathrm{BC}$, have analogies among the monuments from the Northern Black Sea and Transylvania. Another example is that two copper axes found in the Kolomyia region probably belonged to the Caucasian type. Identical sights are known from Hungary. The discovery of a mold for making such axes near Salzburg (Austria) indicates the center of their production in the Danube ${ }^{28}$.

Economic communications between the population of Prykarpattia and Zakarpattia are evidenced by products made of Transcarpathian volcanic glass found in the village of Kornych, Kolomyia district, Ivano-Frankivsk region ${ }^{29}$.

\footnotetext{
${ }^{26}$ Пелещишин М., Крушельницька Л. Етнічна історія східних Карпат у бронзовому віці. Етногенез та етнічна історія населення Українських Карпат : у 4-х т. Львів, 1999. С. 123.

${ }^{27}$ Балагурі Е. Ливарні формочки з поселення пізньобронзової доби біля с. Острівець Гвіздецького району Станіславської області. Ужгородський університет. Серія історичних наук. Ужгород, 1961. № 5. C. $50-52$.

${ }_{28}$ Свєшніков І. Історія населення Передкарпаття, Поділля і Волині в кінці III - на поч. II тис. до н. е. Київ : Наукова думка, 1974. С. 51-52.

${ }^{29}$ Пастернак Я. 3 покутської старовини. Життя і знання. Львів, 1936. Ч. 10. С. 291-292. 
A treasure of bronze objects, consisting of five or seven stacked hemispherical cauldrons, was found in the Kunisivtsi village of Horodenka district. One of the vessels was decorated with a delicate ornament by an ancient master, and around its walls he made cross-shaped ears, and between them - two rows of embossed protrusions that formed a kind of wreath. Below, the ornament was replaced by motifs of "swan necks" embossed symmetrically opposite each other. According to Nataliia Paliichuk, such vessels are a typical example of products from Etruscan workshops, acquired as a result of trade relations, as analogies with the findings were found in Hungary and Bulgaria. The significance of the treasure is confirmed by its preservation in the Vienna Museum ${ }^{30}$.

The Komariv culture (15th-11th centuries BC), which replaced the culture of corded ware or battle axes, is represented by mounds in Stopchatov, Kosiv district, and settlements in Loieva, Nadvirna district. Scholars agree that at the stage of formation of this archaeological culture there was a separation of the Slavic substratum from the Balto-Slavic community. The concept of a threepart division of early Slavs was even proposed as early as the third quarter of the 2nd millennium BC, seeing sprouts of the Western Tšinec culture in the future Western Slavs, the South Tšinec culture in the Eastern ones, and the Komariv culture in the southern ones ${ }^{31}$.

In studying the solar symbolism of Boiko pysanky scientists make the assumption that the symbols of the sun can be found on the ceramics of prehistoric times. As it is known, such symbols are most often traced among the antiquities of the Komariv culture (15th-11th centuries BC), known mainly from cemeteries found on the territory of Prykarpattia.

Not only the tribes of the Corded Ware culture, but also the ethnic group living in the Danube region took part in the formation of the Komariv "Slavic" culture. After arriving from the Carpathians, its representatives had a great influence on the forms and ornamentation of Trypillian culture ${ }^{32}$.

In the Pokutsko-Bukovynian Carpathians, since the Bronze Age, there were many salt-producing complexes, which had no analogues in capacity in Central Europe at that time. There are more than 200 salt-producing sourses within the ethnic Ukrainian lands. The uniqueness of the Loieva saltworks is that a multi-layered section of crops was found here, because salt production continued in that area since the Eneolithic era. Remains of cultural horizons of Trypillian culture, Metnovytsia, Komariv, Noah ones and Thracian Hallstatt are recorded on the site ${ }^{33}$.

\footnotetext{
30 Палійчук Н. Скарби бронзової доби з Городенківських теренів. Ямгорів : літературнокраєзнавчий і мистецький альманах. Городенка, 2005. Ч. 13-14. С. 43.

${ }^{31}$ Березанская С. Средний период бронзового века в Северной Украине. Київ : Наукова думка, 1972. C. 193.

32 Крушельницька Л. Солеварний центр у с. Лоєва Надвірнянського району Івано-Франківської області. Нові матеріали з археологї Прикарпаття і Волині. Львів, 1990. Вип. І. С. 62-64.

${ }^{33}$ Крушельницька Л. Солеварний центр у с. Лоєва Надвірнянського району Івано-Франківської області. Нові матеріали з археологї Прикарпаття і Волині. Львів, 1990. Вип. І. С. 62-64.
} 
Successful salt industry, as a basis for intensive external relations, is confirmed by another discovery in the area of the Kosmach village (Medvezhyi village, "Tymchuchchyna" land type) is a three-thousand-yearold salt production center. Its scale is evidenced by $470 \mathrm{~kg}$ of collected fragments of utensils, which were once used to form salt briquettes. One of the three Trans-Carpathian routes was found to be used for its transportation to consumers. It ran through Hutsul region (Yablunytsia Pass) to Transylvania and the Middle Danube Lowland. The Thracians not only added salt to food, but also used the imported valuable product for the production of metal products. This fact also convincingly confirms the relationship of cultures of the early metal age ${ }^{34}$.

Thanks to the trade and well-established salt production on the Dobromyl Stara Sil - Bolekhiv - Nadvirna - Kolomyia - Kosmach - Suceava section, the population of the Upper Transnistria, as established, received a large influx of various bronze products (swords, axes, sickles, cauldrons and bracelets) of Transylvanian and Semihorod origin. At the same time, on the territory of Prykarpattia, foundry technology was developed among the bearers of the Noah culture. The high level of such production is evidenced by materials from the settlements of Mahala, Ostrivets, Velyka Kamianka, Oleshiv, Kelmentsi, cemeteries (Ostrivets), treasures and some finds ${ }^{35}$.

At the beginning of the Early Iron Age, the spiritual life of the tribes of the Carpathian region continued to undergo intense changes. Evidence of this may be the rock sanctuary of the Goligrad tribes in the Urych village, Skole district, Lviv region. It is located on giant sandstone cliffs, $75 \mathrm{~m}$ above the surrounding valley. The surface of individual rocks is covered with many images. About 270 solar signs are recorded here, among which there are five groups: holes, holes with a rim, disk-shaped, concentric and signs in the shape of an octagon. The closest analogies to the rock reliefs of Urych are found in the north of the Balkan Peninsula in Sakar Mountain, near the Bulgarian villages of Paleokastro and Hlyabovo, on the walls of the Rabisha cave ${ }^{36}$.

Archaeological monuments of the early Scythian period, in particular Kulchytske settlement, testify to the diversity of cultural components of the ancient population of Prykarpattia. Its appropriate contours are evidenced by the fact that it is oval in shape, measuring $900 \times 1,100 \mathrm{~m}$ with an area of about 80 hectares. A similar example is the settlement in Krushelnytsia (Skole Beskids).

The discovery of 1885 can testify to the cultural influences of the Celtic population in the La Tène period on the natives of Prykarpattia. Then, between Synevydsk and Stinava Nyzhnia (Skoliv Beskids), the burial of a

\footnotetext{
${ }^{34}$ Крушельницька Л., Бандрівський М. Солевиробництво на Гуцульщині три тисячоліття тому. Історія Гуиульщини. Львів : Логос, 1999. Т. 4. С. 196-210.

${ }^{35}$ Балагурі Е., Бідзіля В., Пеняк С. Давні металурги Українських Карпат. Ужгород : Карпати, 1987. C. 29 .

${ }^{36}$ Бандрівський М. Про «поганські камені» в Карпатах. Археологія. Київ. 1989. № 3. С. 109-116. 
Celtic warrior was discovered, whose grave was located in a mound of the Eneolithic period. There was an iron sword near the deceased. Also, there was a part of another sword, stirrups, fishing rod, two pottery vessels. Until recently, it was believed that this was the first and almost the only trace of the arrival of the Celts in Boikivshchyna. As Ya. Pasternak points out, in the last centuries $\mathrm{BC}$ - the time of the highest development of their political power, they carried out a kind of trade expansion and in search of new markets for their developed industry, as at that time, occupied the Czech Republic, Moravia, Silesia and came to Posanie through Western Galicia.

According to a well-known archaeologist, the Celts first brought with them various iron products to the Subcarpathians, and then crossed the Veretskyi Pass to Transcarpathia ${ }^{37}$. Celtic influence in the Upper Transnistria and the Carpathians is not disputed today, as from the middle of the 1st millennium $\mathrm{BC}$ their advance through the territories of modern Bohemia and Moravia to Transnistria caused the economic, political and cultural rise of this people in the Hallstatt period, and later in the La Tène period (4th-2nd centuries BC).

The penetration of the Celtic population into the Slavic world is believed to have contributed to the rise of the local economy. Then in the Ukrainian Carpathians, according to scientists, a number of iron mining centers appeared, metalworking was radically improved, and pottery workshops began to function. The Celts brought to the indigenous inhabitants of the Carpathians a special type of housing with a deep pillar structure and a tent roof. According to researchers, funeral rites acquired new features; in particular, in the cemeteries of that time, archaeologists discovered bent swords and spearheads.

The presence of the Celtic ethnic element is said to have had a marked effect on the Slavic metallurgical terminology. Linguists speak confidently about the Celtic cultural expansion. It is noted that all available hydronyms of Transnistria indicate the Celtic political basis and the Slavic ethnic majority, which lived there at the turn of the old and new era ${ }^{38}$.

\section{Prykarpattia and the Ukrainian Carpathians in the period of the early Slavs and Kievan Rus}

An important period of settlement of the Carpathian region is associated with the history of Kievan Rus. The analysis of this section focuses on the period of the early Slavs, which preceded its formation. It is known about their appearance on the historical arena of Europe as a numerous and formed socio-political force before the middle of the first millennium AD. It is noteworthy that the early Slavic population of Boikivshchyna on both sides of the Carpathians was then the westernmost part of the "populous" (according

\footnotetext{
${ }^{37}$ Пастернак Я. Бойківщина у глибині віків. Бойківщзина. Філадельфія; Нью-Йорк, 1980. С. 11-12.

38 Габорак М. Топонімія Покуття та деяких прилеглих територій : етимологічний словникдовідник. Івано-Франківськ : Місто НВ, 2013. 932 с.
} 
to Jordan, the Byzantine historian of Gothic origin of the 6th century) protoUkrainian tribes of Antes ${ }^{39}$. However, here we must pay attention to M. Hrushevsky's designation of the threshold of historical times for the Ukrainian people, which is proposed to be considered the 4th century (before it, Ukrainians can be "spoken of only as part of the Slavic group") ${ }^{40}$.

In the light of modern concepts of the historical homeland of the IndoEuropeans, a special place is given to the Danube region. The "Tale of Bygone Years" repeatedly points to the settlement of the early Slavs along it. Numerous toponyms that have survived in Hungary, Romania and the Ukrainian Carpathians testify to the Slavic settlement of the DanubeCarpathian region. As noted by researchers of Celtic history, several consonants characteristic for archaic Slavic phrases - brda, vra, gvda, vkra, skra, poprad, gor, kharb, grb - also occur in many Carpathian toponyms ${ }^{41}$.

At the turn of the 9th and 10th centuries, the Kyiv chronicler called the inhabitants of the Carpathians white Croats and considered their historical destiny along with other ancient Russian tribes - Polyany, Severyany, Drevlyany, Duliby, Tivertsy and Ulychi. White Croats then inhabited the upper Transnistria, Posanie and the adjacent Carpathian Foothills, and on the southern side of the Carpathians - the territory of present-day Eastern Slovakia and the western part of Carpathian Ukraine.

The conclusion of the Ukrainian ethnologist Sviatoslav Semeniuk, who studied the action of the Wallachian colonization in Mezhyrich (the westernmost part of the Ukrainian Carpathians), is relevant. The scholar believed that the 8th-10th centuries became the apogee of the territorial expansion of the Ruthenians in Central and Eastern Europe. Eventually, their habitat, especially in the West, began to narrow significantly. "Therefore, only ignorant historians can be skeptical of K. Bahrianorodnyi's reports about Greater Croatia from the Prut to Bavaria or wonder at Prince Sviatoslav's intentions to move the capital of Kievan Rus to the Danube. In fact, not only Wallachia, but also northern Bulgaria was then inhabited by Ruthenians, and on the Danube there is still a city with a very eloquent name Ruse (this is where Sviatoslav intended to arrange his new capital)"42.

Information about Greater Croatia is supplemented by Eastern written sources dating from the 9th-10th centuries. From the work on the Slavs, preserved in the editions of Ibn Ruste $(\dagger$ 903) "Al Alak-av-Nafisa", we learn about the Croatian country, its capital Jarvat, or Hordat, the name of which orientalists read as $\mathrm{Croat}^{43}$.

\footnotetext{
${ }^{39}$ Баран В.Д. Давні слов’яни. Київ : Альтернативи, 1998. С. 23.

${ }^{40}$ Грушевський М. Історія України-Руси : в 11 т. 12 кн. / редкол.: П. Сохань (голова) та ін. Київ : Наук. думка, 1994. Т. 1. С. 18.

41 Ідзьо В. Вплив кельтів на розвиток слов'янського етносу і слов'янської державності. Бойки. Дрогобич, 2002. С. 60 .

42 Семенюк С. Українські історико-етнічні землі (Польща, Угорщина, Румунія, Словаччина, Чехія, Австрія, Саксонія). Львів : Апріорі, 2011. С. 347-348.

${ }_{43}$ Корчинский О. Городище-гигант в предгорьях Украинских Карпат. Tpуды V Международного Конгресса славянской археологии. Москва, 1987. Т. 3. Вып. Іа. С. 111-112.
} 
An archaeological expedition led by O. Korchynskyi searched for Croatian monuments in Transnistria and studied the finds. As a result, in 1981-2013, several dozen new Slavic hillforts, settlements, and cemeteries were opened. Unknown Slavic pagan sacred centers of the 9th-10th centuries were discovered. One of the largest cities in Greater Croatia at that time was a fortress located on the Stiljsko hillfort. Its medieval settlement is known from documents of the Vatican archives (sources date back to the thirties of the 14th century). The study of monuments confirmed that it was one of the largest cities in the Slavic world at the turn of the 9th-10th centuries. Fortifications in the form of earthen ramparts and ditches $10 \mathrm{~km}$ long, enclosing an area of 250 hectares, preserved from a large Slavic settlement built on a high wooded plateau along the steep left bank of the Kolodnytsia River.

Numerous settlements, cemeteries and pre-Christian cult centers have been found in the vicinity of the Stiljsko hillfort. In the village of Iliv, $2.5 \mathrm{~km}$ to the east, on a high mountain above the Ilovets River, a pagan sanctuary functioned in the 9th and early 11th centuries. In addition, pre-Christian religious centers were discovered near the city of Mykolaiv, Lviv region and in the villages of Dibrova and Velyka Volia of Mykolaiv district ${ }^{44}$.

In the Arab sources of the 9th-10th centuries, evidence of the spiritual culture of the population of Prykarpattia, which was part of the Greater Croatia state, were found. It is repeatedly mentioned that it is a fireworshiper, and hits religion is closely associated with agriculture. It is also noted that the remnants of the cult of the bull were preserved here, and great respect is paid to the god of the sky and fertility (some researchers see Sviatovyd in him). According to al-Masudi, a cave temple is dedicated to him in the Black Mountain tract, where a statue of this pagan god stands. Croatians, according to Arab travelers, are very fond of music, play eightstringed lutes, harps and pipes ${ }^{45}$.

Probably, during the residence of white Croats in the Carpathians there were separate settlements, the inhabitants of which were shepherds, who moved with the flocks along mountain pastures. Belonging of white Croats from Transcarpathia to the border areas of the Old Russian state led to the spread of their new ethnonym "Rusyn"

An important period of development of the Ukrainian Carpathians came after the entry of this territory together with the territories of Cherven "cities" into Kievan Rus. The region became its western outpost, which in turn influenced the development of old Croatian "cities" and the establishment of

\footnotetext{
44 Корчинський О., Шишак О. Стільський комплекс IX-XI ст. (За даними найновіших археологічних досліджень). Еволючія розвитку слов 'янських градів VIII-XIV cm. у передгір'ї Kapnam $i$ Tатр : Міжнародна наукова конференція : тези доповідей і повідомлень. (м. Львів, 27-29 вересня 1994 р.). Львів, 1994. С. 49.

45 Овчинніков О. Культура Великої Хорватії X ст. за матеріалами арабських географів. Бойківщина: Історія та сучасність. Львів; Самбір, 1995. С. 70.

${ }^{46}$ Гошко Ю.Г. Населення Українських Карпат XV-XVIII ст. Київ : Наукова думка, 1976. 120 с.
} 
new ones. Some of them were economic and administrative centers, other hillforts became settlements of boyars, trade and craft centers. Many fortresses housed military garrisons that defended the borders of the Przemyśl principality, and later - the Galician lands.

Traces of contemporary human activity testify to the active settlement of the Carpathian lands during the princely period. They have been preserved in the form of destroyed ramparts, sites of settlements, as well as in the names of mountains, glades, forests, tracts, etc. For example, in the village of Sheshory there is a place called "Kernychnyi Horod", and in the Shipit village - a tract "Horodyshche". The toponyms like "Prince's Forest", "Boyarsky Stream", "Prince's Mountain", "Prince's Glade" testify to the ancient Russian influences in the villages of Vyzhnii Bereziv, Dori, Liuchky, Chorni Oslavy ${ }^{47}$.

During the princely times (10th-13th centuries) there were at least 12 hillforts and 10 settlements in Hutsul region. In particular, hillforts were found in Horody, Kobaky, Kuty, Pistyna, Stari Kuty, Sheshory, Shipit (Kosivshchyna), Barvinkova (Verkhovyna), Delyatyn, Loieva and Pniv (Nadvirnianshchyna), and settlements - in Akryshor, Horishnii Bereziv, Kosmach, Tekuch, Yavoriv (Kosiv region), Iltsi, Krasnoillia (Verkhovyna region), Bili Oslavy, Zelena and Mykulychyna (Nadvirnianshchyna).

Important data were obtained by scientists during the study of the settlement of the 10th-12th centuries in the town of Kuty, Kosiv district. The defensive object, located on a mountain called Horodyshche, is now represented by traces of earthen fortifications and a soil necropolis with the body-layings of princely times ${ }^{48}$.

Numerous names (Horodok, Horod, Halych, Mohylky, Taboryshche, and Zamchyshche) testify to the intensive development of life in the Old Russian period in Prykarpattia and, in particular, in Hutsul region. They often sound in the names of tracts: Horodok Lis in the village of Chornyi Potik, Horodok Kernychnyi in the village of Sheshory, Halycha Hora in the village of Moskalivka, and Hora Halycha in the village of Rozhniv.

There are many toponymic names that to some extent characterize the life of the population in the period of Kievan Rus. These are, in particular, such names of villages as Kniazhe (above the river Cheremorsh), Kniazhdvir (above the river Prut), Kniazha hora (near Liuchka), Kniazha poliana (in Chorni Oslavy), Knyazhyi Lis (in Vyzhnii Bereziv), Boiarske Pasovyshche (in Zelena), Boiarskyi potik (in Dora) ${ }^{49}$.

In the pre-Mongol period, the Carpathian line of defense singled out strongholds that appeared in the foothills: Vyhoda, Bubnyshche, Syniovydne, Tustan, Staryi Sambir. These defense centers controlled the main roads and

\footnotetext{
${ }^{47}$ Грабовецький В. Гуцульщина XIII-XIX століть. Історичний. Львів : Вища школа, 1982. С. 25.

${ }^{48}$ Ратич О. Давньоруські археологічні пам'ятки на території західних областей УРСР. Київ : Видво АН УРСР, 1957. С. 56.

${ }^{49}$ Грабовецький В. Історія Гуцульщини. Косів : Писаний Камінь, 2013. С. 22. 
were a kind of "gate" to Vyshkivskyi, Skotarskyi, Voritskyi (Veretskyi) "Russian Way", Uzhytskyi passes ${ }^{50}$.

In the times of the Galicia-Volyn principality, before the invasion of nomadic hordes, Prykarpattia was a densely populated region. There is reason to believe that there were about 200 settlements. Among them there are five chronicle cities: Halych (898), Tysmenytsia (1143), Sniatyn (1158), Tovmach (1213), Kolomyia (1240), more than 60 hillforts and more than 120 settlements (unfortified rural houses).

Despite the loss of population during the devastating campaign of Batu, Horde invasions, epidemics, continuous military struggle for the GalicianVolyn lands, they were a populous territory. Among the documentary evidence of the settlement of the region, which dates back to the second half of the 14th century, there are mentions of the settlements of Mykytyntsi (1365), Utoropy (1367), Pistyn (1375). Polish missionaries Janko of Charnków (1382) and Władysław Abragan (1390), during their stay in Prykarpattia in the last quarter of the 16th century, noted the population density of the region and pointed to the local network of cities ${ }^{51}$.

According to P. Siredzhuk, the settlement of the foothills and mountains took place mainly due to the socially and economically active elements of the Ukrainian population, i.e. those peasants who wanted and were not afraid to boldly develop virgin lands. Secondly, the royal government, preferring to have a firm foothold in the conquered Ukrainian lands, provided estates to the nobility and magnates ${ }^{52}$.

The problem of the so-called Wallachian colonization of the Carpathians in the 10th-18th centuries has been hotly debated in European historiography for a long time. It is well known that part of them (mostly the territory of presentday Romania) was once inhabited by Wallachians. But the question of the epicentre of their colonization, its directions and forms still remains open. The hypothesis of the settlement of the Ukrainian Carpathians was one of the first put forward by the Polish researcher A. Stadnicki. He, and later his followers, claimed that in the Middle and Late Middle Ages those territories were colonized by Wallachian settlers. Over time, they were assimilated by the Ukrainian ethnic group ${ }^{53}$.

Similar views have been expressed in modern Polish historiography. In particular, Andrzej Wielocha believes that "a new form of management was necessary for the development of mountainous areas, to which Wallachian shepherds turned out to be more adapted. And they with the right of owners became pioneers in the gradual development of mountainous areas, but the majority of the population were, obviously, Ruthenians from the foothills. In

\footnotetext{
${ }^{50}$ Рожко М. Тустань - давньоруська наскельна фортеця. Київ : Наукова думка, 1996. С. 164-183.

${ }_{51}^{51}$ Сіреджук П. Як і коли заселялось Прикарпаття. Жовтень. Львів, 1984. № 2. С. 102.

${ }_{52}$ Ibid.

${ }^{53}$ Stadnicki A. O wsiach tak zwanych wloskich na pilnocsnyh stoku Karpat. Lwow, 1848. P. 7-10.
} 
this process, the various influences of the people who came to the mountains over time assimilated and gradually transformed, and as a result there was another, different culture, exceptional on all sides and original one. This transformation, the absorption of something new, lasted until about the middle of the 18th century, after which Hutsul culture, continuing to accept fresh trends from outside, began to radiate and influence its neighbors" ${ }^{\$ 4}$.

Some researchers identify the issue of colonization of the Ukrainian Carpathians with the spread of the so-called Wallachian law. It should be noted that for a long time in the area of Ukrainian ethnic lands, in addition to Russian law, there was a German (Magdeburg) law and Polish state law. From the 13th to the 18th century, Wallachian customary law also functioned in mountainous areas, which probably influenced the formation of the cultural identity of the region.

The essence of the concept of "Wallachian colonization of the Carpathians" and the origin of the term "Wallachians" should be clarified. According to most researchers, the first written mention of the bearers of the ethnonym "Wallachians" was recorded in the Balkans. According to the Czech scholar $\mathrm{K}$. Kadlec, the Wallachians were the population of the former Roman provinces. In the process of "resettlement of peoples", they assimilated with the Slavs. In the 13th century, the Wallachians arrived in Semihorod (Transylvania) as the already formed people. Their representatives called themselves Romanians, and neighboring peoples called them "Wlochs", "Wlachs", "Wallachians" and other similar names. These cognate words have been found to be of German origin, apparently from the word "gall", and the German population has traditionally formed the words "walh", "vealh", from which the Slavic names are derived: "Wlach", "Wallach", "Wallachian".

The earliest mention of the Wallachians in the chronicle dates back to 898 . The "Tale of Bygone Years" reports that the Ugrians, coming from the east, moved through the Carpathian Mountains and began to fight the local population - the Wallachians and Slavs. The Wallachians were expelled, and the land inhabited by the Ugric people was called Hungarian ${ }^{55}$.

Another notice about the Wallachians is found in the work of the Byzantine general Kekavmen. He tells of the assassination of David, one of the four comitopules who headed the First Bulgarian Kingdom. It was this ruler who was killed by some Wallachian travellers ${ }^{56}$.

The Byzantine historian Honiat Akominat mentions that the lands of the Wallachians stretched near the Galician principality. He reports that the contender for the Byzantine throne Andronicus, fleeing persecution after a failed conspiracy, reached the Galician land, where he felt safe. But some

\footnotetext{
${ }_{55}^{54}$ Вєльоха Анджей. Про Гуцульщину. Гори Гуиульщъини. Краків, 2006. С. 62.

55 Літопис Руський за Іпатським списком / переклад Леонід Махновець. Київ : Дніпро, 1990. С. 14.

56 Литаврин Г. Влахи византийских источников X-XIII вв. Юго-восточная Европа в эпоху феодализма. Кишинев, 1973. С. 95.
} 
Wallachians, learning of his whereabouts, tried to return the fugitive to the emperor $^{57}$.

Moldovan researchers N. Mohov and L. Polevoy believe that in the 14th15 th centuries, due to the seizure of fertile lands and pastures of communities, the increase of duties by Hungarian feudal lords, migration processes intensified among the Wallachian population. This forced many of its representatives to leave their native places and relocate to the territory of present-day Moldova and adjacent Carpathian and Carpathian lands ${ }^{58}$.

In Soviet historiography, there were two opposing positions on the appearance of the Wallachian element in the Eastern Carpathians. Some researchers date it to the 13th-14th centuries; other experts connect the appearance of the Wallachians with an earlier period. P. Siderzhuk declared the position of modern historical science. According to his argument based on archival materials, there was no mass resettlement of the Wallachian population, which can be characterized as the colonization of the Ukrainian Carpathians, neither at the stage of emergence of the first villages (9th-16th centuries), nor at the stage of formation of most settlements (17th-18th centuries) ${ }^{59}$.

Prince Roman Mstislavovich (1173-1205) pursuing an active foreign policy united the Volyn and Galician lands into a single Galicia-Volyn principality in 1199. The new state reached its peak under Prince Danylo Halytsky (1205-1264). He had great authority in Europe, waged an active struggle against the Mongol-Tatars and received the royal crown. According to chronicles, at the end of the 13th century there were about 80 cities in the country. They became significant centers of crafts and trade, outposts in the fight against enemies, among them: Lutsk, Kholm, Halych, Belz, Volodymyr, Ustyluh, Kamin, Turiisk, Chortoryisk and others ${ }^{60}$.

\section{CONCLUSIONS}

The study of the cultural relations of Galicia-Volyn Rus needed to outline the characteristics of its settlement in the prehistoric era. It is believed that human penetration into the territory of modern Ukraine began through the Carpathian passes. Its ancient origins are confirmed by archaeological discoveries. Thanks to them, it is know about the oldest sites of primitive people. Many different cultural layers, which successively replaced each other from the Acheulean era to the Iron Age, were managed to find. The results of archaeological research have traced the evolution of the culture of making tools. Paleolithic hunters left many such objects, some of which were perhaps

\footnotetext{
57 Шишмарев В. Романские языки Юго-Восточной Европы и национальный язык Молдавской ССР. Вопросы молдавского языкознания. Москва, 1953. С. 103.

${ }_{58}$ Полевой Л. Очерки исторической географии Молдавии XIII-XV вв. Кишинев, 1979. 206 с. C. 146 .

Сірержук П., Фриз В. Чи була волоська колонізація Українських Карпат? Дзвін. 1992. № 3-4.

${ }^{60}$ Грушевський М. Історія України-Руси : в 11 т. 12 кн. / редкол.: П. Сохань (голова) та ін. Київ : Наук. думка, 1994. Т. 1 : До початку XI віку. (Пам'ятки іст. думки України). 736 с.
} 
the most complex among the synchronous complexes of Central Europe. The allocation of periods of the Ukrainian Carpathians settlement contributed to a clear vision of natural changes in the economic activities of ancient society, the development of crafts; pre-Christian cult centers functioned, different ethnic groups interacted, which was due to the geographical location of these areas on the "border of cultures". The study of the oldest manifestations of artistic creativity of the then population of the Carpathians and Prykarpattia reveals a lot of information about people's lives, their work, beliefs, worldview, ethnocultural interactions. The latter was primarily facilitated by salt production in the Pokutsko-Bukovynian Carpathians. The discovered saltworks complexes testify to the lively trade with many European countries. Transcarpathian routes were used for this purpose. Naturally, this became a guarantee of mutual borrowing of artistic heritage. In their spread, a certain role belongs to the penetration of the Celtic population into the local Slavic world, the influence of newcomers on its metal production. The Kyiv chronicler's consideration of the historical destiny of white Croats at the turn of the 9th-10th centuries as inhabitants of the Carpathians and Prykarpattia valleys, along with other ancient Russian tribes, testified to their connection in a common state - Kievan Rus, a new stage of socio-economic development of its western territories.

\section{SUMMARY}

The publication reveals the features of the long and complex history of the settlement of the Carpathians and Prykarpattia. Intense cultural contacts between different groups of the ancient population were formed in line with the fateful ethno-forming processes. Most of the Bronze Age archaeological cultures of this area reflect the material and spiritual world of the SlavicBaltic-Germanic community. The text points out the important role in the genesis of modern European peoples, in particular the Slavs. The Thracian, Illyrian, and Celtic peoples, and later Romanians and Hungarians (ethnic groups, neighbouring Ukrainians of the Carpathians and Prykarpattia) also played a significant role in their history. At the same time, this historical, ethnographic and cultural region developed under the influence of many other political, management and economic factors. At the same time, it had close ethnically based ties with the bearers of Thracian culture in present-day Slovakia, Hungary, and Romania.

During the disintegration of the primitive communal system, in conditions of socio-economic shifts, pagan beliefs and rituals changed. First of all, religious cults became more complicated, and in addition to traditional worship of natural forces and individual objects in the open air, worship services were practiced in special places of worship. 
The new studies results of the life of the then population of Prykarpattia became the basis for a better vision of their pagan beliefs ambiguous and complex in form and essence cultural phenomenon. It once again convinces of the highly developed spirituality of ancient Ukrainians.

Despite the difficult natural conditions and turbulent socio-historical processes, the local population has for centuries preserved ancient traditions in which the remnants of the pagan worldview and ritual behavior dictated by the Christian cult are inextricably intertwined.

Gradually, the original cultural tradition was strengthened on the territory of the Galicia-Volyn principality. By synthesizing the influences of Great Moravia and Kyiv and embodying the character of the Byzantine Christian heritage, it became not only one of the cornerstones of the national art school formation, but also ensured its continuous development.

\section{REFERENCES}

1. Андрухів I. Давня історія України та рідного краю з найдавніших часів до IX ст. Івано-Франківськ, 1997. 136 с.

2. Балагурі Е., Бідзіля В., Пеняк С. Давні металурги Українських Карпат. Ужгород : Карпати, 1987. 128 с.: іл.

3. Балагурі Е. Ливарні формочки з поселення пізньобронзової доби біля с. Острівець Гвіздецького району Станіславської області. Ужгородський університет. Серія історичних наук. Ужгород, 1961. № 5. C. $50-52$.

4. Бандрівський М. Археологія Косівщини і суміжного 3 нею краю. Старожитності Косівщини. Історичні нариси. Івано-Франківськ : «ЛілеяHB», 1997. С. 63-82.

5. Бандрівський М. Про «поганські камені» в Карпатах. Археологія. Київ. 1989. № 3. С. 109-116.

6. Баран В. Давні слов’яни. Київ : Альтернативи, 1998. 335 с.

7. Березанская С.С. Средний период бронзового века в Северной Украине. Киев : Наукова думка, 1972. 271 с.

8. Вєльоха Анджей. Про Гуцульщину. Гори Гуиульщиини. Краків, 2006. C. $49-88$.

9. Винокур І., Телегін Д. Археологія України. Тернопіль : Навчальна книга - Богдан, 2005. 480 с.: іл.

10. Відейко М. Трипільська цивілізація. Київ : Наш час, 2008. 160 с.

11. Габорак М. Топонімія Покуття та деяких прилеглих територій : етимологічний словник-довідник. Івано-Франківськ : Місто НВ, 2013. $932 \mathrm{c.}$

12. Гошко Ю. Населення Українських Карпат XV-XVIII ст. Київ : Наукова думка, 1976. 120 с. 
13. Грабовецький В. Гуцульщина XIII-XIX століть. Львів : Вища школа, 1982. 152 с.

14. Грабовецький В. Історія Гуцульщини. Косів : Писаний Камінь, 2013. $244 \mathrm{c}$.

15. Грушевський М. Історія України-Руси : в 11 т. 12 кн. / редкол.: П. Сохань (голова) та ін. Київ : Наук. думка, 1994.

16. Даркевич В. Топор как символ Перуна в древнерусском язычестве. Советская археология. 1961. № 4. С. 91-101.

17. Ідзьо В. Вплив кельтів на розвиток слов'янського етносу i слов'янської державності. Бойки. Дрогобич, 2002. С. 60-67.

18. Клапчук М., Клапчук-Делятин В. Історико-етнографічний нарис Делятинщини (від найдавніших часів до 1939 року) : монографія. Делятин, 2000. 91 с.: іл.

19. Клапчук М. Новые данные о палеолите и мезолите Прикарпатья. Советская археология. Москва, 1983. № 4. С. 103-117.

20. Корчинский О. Городище-гигант в передгорьях Украинских Карпат. Tруды V Международного Конгресса славянской археологии. Москва, 1987. Т. 3. Вып. Іа. С. 111-115.

21. Корчинський О., Шишак О. Стільський комплекс IX-XI ст. (За даними найновіших археологічних досліджень). Еволющія розвитку слов'янських градів VIII-XIV cm. у передгір'ї Kapnam $i$ Tатр : Міжнародна наукова конференція : тези доповідей і повідомлень. (м. Львів, 27-29 вересня 1994 р.). Львів, 1994. С. 48-50.

22. Крушельницька Л. Найдавніше населення Карпатського регіону. Украйнські Карпати. Київ, 1989. С. 20-21.

23. Крушельницька Л. Солеварний центр у с. Лоєва Надвірнянського району Івано-Франківської області. Нові матеріали з археологіі Прикарпаття і Волині. Львів, 1990. Вип. І. С. 62-64.

24. Крушельницька Л., Бандрівський М. Солевиробництво на Гуцульщині три тисячоліття тому. Історія Гуиульщини. Львів : Логос, 1999. Т. 4. С. 196-210.

25. Лаврук М. Гуцули Українських Карпат : етнографічне дослідження. Львів, 2005. 286 с.

26. Ленартович О. Елементи орнаменту посуду культури лінійнострічкової кераміки з поселення Тадані. Наукові студіï. Історикокраєзнавчий музей. м. Винники. Львів : «Растр-7», 2012. Вип. 5. С. 3-19.

27. Ленартович О. Керамічний комплекс поселення культури лінійнострічкової кераміки Котоване I. Археологічні дослідження Львівського університету. Львів, 2010. Вип. 13. С. 71-91.

28. Литаврин Г. Влахи византийских источников X-XIII вв. Юговосточная Европа в эпоху феодализма. Кишинев, 1973. 124 с. 
29. Літопис Руський за Іпатським списком / переклад Леонід Махновець. Київ : Дніпро, 1990. 591 с.

30. Махнік Я. Інтердисциплінарні дослідження над найдавнішим заселенням польських і словацьких Карпат. Бойківщчина: Iсторія та сучасність : матеріали Міжнародного історико-народознавчого другого семінару «Населення Бойківщини в контексті загальнокарпатського етнокультурного розвитку». (м. Самбір, 14-16 вересня 1995 р.). Львів; Самбір, 1995. С. 58-59.

31. Мацкевой Л. До питання про найдавніше минуле Косівщини. Старожитності Косівщини. Історичні нариси. Івано-Франківськ : «Лілея-НВ», 1997. С. 49-62.

32. Овчинніков О. Культура Великої Хорватії Х ст. за матеріалами арабських географів. Бойківщина : Історія та сучасність. Львів; Самбір, 1995. C. 69-70.

33. Палійчук Н. Скарби бронзової доби з Городенківських теренів. Ямгорів : літературно-краєзнавчий і мистецький альманах. Городенка, 2005. Ч. 13-14. С. 41-43.

34. Пастернак Я. Бойківщина у глибині віків. Бойківщина. Філадельфія; Нью-Йорк, 1980. С. 7-19.

35. Пастернак Я. До проблеми поширення i хронології лінійнострічкової кераміки в Європі. Авгсбург, 1948. 3б. 2. С. 3-9.

36. Пастернак Я. 3 покутської старовини. Життя $i$ знання. Львів, 1936. Ч. 10. С. 291-292.

37. Пастернак Я. Шнурова могила в Кульчицях. Літопис Бойківщини. Самбір, 1936. Ч. 7. С. 1-3.

38. Пелещишин М., Конопля В. Східнокарпатський регіон у первісності (кам'яний вік). Етногенез та етнічна історія населення Українських Карпат. Археологія та антропологія. Львів, 1999. Т. І. C. $115-144$.

39. Пелещишин М., Крушельницька Л. Етнічна історія східних Карпат у бронзовому віці. Етногенез та етнічна історія населення Українських Карпат: у 4-х т. Львів, 1999. с. 123.

40. Полевой Л. Очерки исторической географии Молдавии XIII-XV вв. Кишинев, 1979. 206 с.

41. Ратич О. Давньоруські археологічні пам'ятки на території західних областей УРСР. Київ : Вид-во АН УРСР, 1957. 96 с.

42. Рыбаков Б. Макрокосм в микрокосме народного искусства. Декоративное искусство. 1975. № 1. С. 28-36.

43. Рожко М. Тустань - давньоруська наскельна фортеця. Київ : Наукова думка, 1996. 240 с.

44. Свєшніков І. Історія населення Передкарпаття, Поділля і Волині в кінці III - на поч. II тис. до н. е. Київ : Наукова думка, 1974. 204 с. 
45. Семенюк С. Українські історико-етнічні землі (Польща, Угорщина, Румунія, Словаччина, Чехія, Австрія, Саксонія). Львів : Апріорі, 2011. $638 \mathrm{c}$.

46. Сірержук П., Фриз В. Чи була волоська колонізація Українських Карпат? Дзвін. 1992. № 3-4. С. 142-147.

47. Сіреджук П. Як і коли заселялось Прикарпаття. Жовтень. Львів,1984. № 2. С. 102-108.

48. Скорик М. Бойківські писанки. Літопис Бойківщ⿻ини. 1934. Ч. 4. C. 23-28.

49. Ткачук Я. Мистецтво Покуття. Історико-етнографічне та мистеиьке життя Покуття: минуле і сьогодення : матеріали науковотеоретичної конференції з питань дослідження історико-етнографічного регіону Покуття (м. Коломия, 9 жовтня 2011 року). Коломия : Вік, 2013. C. 56-69.

50. Черниш О. До питання про час і шляхи найдавнішого заселення східних Карпат людиною давнього кам'яного віку. Нові матеріали $з$ археологї̈ Прикарпаття і Волині. Львів, 1992. Вип. 2. С. 12-13.

51. Шишмарев В. Романские языки Юго-Восточной Европы и национальный язык Молдавской ССР. Bonросы молдавского языкознания. Москва, 1953. 124 с.

52. Щербаківський В. Основні елементи орнаментації українських писанок та їх походження. Пращі відділу українознавства. Київ; Оттава, 1990. T. 7. C. 3-29.

53. Stadnicki A. O wsiach tak zwanych wloskich na pilnocsnyh stoku Karpat. Lwow, 1848. P. 7-10.

\section{Information about author: \\ Chuyko O. D.,}

Candidate of Arts Criticism, Associate Professor, Professor at the Department of Design and Theory of Art History Vasyl Stefanyk Precarpathian National University 57, Shevchenko str., Ivano-Frankivsk, 76018, Ukraine 